\title{
The Epidemiology and Trend of Hepatitis C Infection in Hamadan Province: West of Iran, 2011-2016
}

\author{
Hamadan Bölgesi'nde Hepatit C Enfeksiyonunun Epidemiyolojisi ve Trendi: Batı İran, \\ 2011-2016
}

\author{
(1) Salman KHAZAEI1, (1) Arash MOFARRAH-ZAT2, (1) Shahrzad NEMATOLLAHI3, (1) Ensiyeh JENABI4, \\ (1) Mohammad MIRZAEI1, (1) Seyyed Jalal BATHAEI2, (1) Manoochehr SOLGI1, (1) Jalaledin AMIRI2
}

\author{
${ }^{1}$ Department of Epidemiology, School of Public Health, Hamadan University of Medical Sciences, Hamadan, Iran \\ 2Deputy of Health, Hamadan University of Medical Sciences, Hamadan, Iran \\ ${ }^{3}$ Department of Epidemiology \& Biostatistics, School of Public Health, Tehran University of Medical Sciences, Tehran, Iran \\ 4 Pediatric Developmental Disorders Research center, Hamadan University of Medical Sciences, Hamadan, Iran
}

\begin{abstract}
Objectives: Hepatitis C virus (HCV) is a blood-borne virus which is transmitted through the exposure to small amounts of blood. The objective of this study was to investigate trend and epidemiological pattern of hepatitis $C$ infection during seven successive years in Hamadan province during 2011-2016.

Materials and Methods: This cross sectional study was conducted on the new cases of HCV ( $n=803)$ who were recorded in the deputy of health of Hamadan University of Medical Sciences. The Cochran-Armitage test was used to investigate the changes in the trend of the disease according to various demographical and clinical characteristics. Incidence rates of HCV were estimated by district for 2016.

Results: Totally, 705 (87.8\%) cases were male and 98 (79.7\%) were urban dwellers and the highest proportion of the cases $(51 \%)$ belonged to the age group of 25-44 years. The overall incidence rate of HCV infection in Hamadan province was 5.26 per 100.000 in 2016, while the southern counties had higher incidence rate compared to the northern parts. Only $8.1 \%$ of cases were assessed due to clinical symptoms.

Conclusion: Our results showed that HCV has a decreasing trend for both genders in Hamadan province and is most prevalent among males, age group of 25-44 years, married people and urban dwellers. Therefore, educational programs for the transmission and prevention of hepatitis $C$ in the community and for high-risk groups should be conducted with the management of health centers and mass media. Keywords: Hepatitis C, infection, incidence, trend, Iran
\end{abstract}

\section{$0 ̈ Z$}

Amaç: Hepatit C virüsü (HCV), küçük miktarda kanla temas yoluyla bulaşan bir virüstür. Bu çalışmada, 2011-2016 yılları arasında, Hamadan bölgesinde ardışık yedi yıl boyunca hepatit C enfeksiyonunun trendi ve epidemiyolojik paterninin araştırıması amaçlanmıştır.

Gereç ve Yöntemler: Bu kesitsel çalışma, Hamadan Tıp Bilimleri Üniversitesi sağlık yardımcıı̆ı̆ında kayıt altına alınan yeni HCV olguları ( $n=803$ ) ile yürütülmüştür. Çeşitli demografik ve klinik özelliklerine göre hastalığın trendindeki değişimleri araştırmak için CochranArmitage testi kullanılmıştır. HCV insidansı 2016 yııına kadar ilçe bazında değerlendirilmiştir.

Bulgular: Toplamda olguların 705'i $(\% 87,8)$ erkek, 98'i $(\% 79,7)$ şehirli olup, olgular (\%51) çok yüksek oranda $25-44$ yaş grubuna aitti. Hamadan bölgesindeki HCV enfeksiyonunun genel insidans oranı 2016 ylında 100.000'de 5,26 iken, güney bölgeleri kuzey bölgelerine göre daha yüksek insidans oranına sahipti. Olguların sadece \%8,1'i klinik semptomlar nedeniyle değerlendirildi.

Sonuç: Elde ettiğimiz sonuçlar, HCV'nin Hamadan bölgesinde her iki cinsiyet için azalan bir trende sahip olduğunu ve en yaygın olarak; erkekler arasında, 25-44 yaş grubunda, evli insanlarda ve şehirlilerde görüldüğünü göstermiştir. Bu nedenle, toplumda hepatit C'nin bulaşmasına ve önlenmesine yönelik ve yüksek riskli gruplar için hazırlanan eğitim programları, sağlık merkezlerinin ve kitle iletişim araçlarının yönetimi ile birlikte yürütülmelidir.

Anahtar Kelimeler: Hepatit C, enfeksiyon, insidans, trend, Iran

Khazaei S, Mofarrah-Zat A, Nematollahi S, Jenabi E, Mirzaei M, Bathaei SJ, Solgi M, Amiri J. The Epidemiology and Trend of Hepatitis C Infection in Hamadan Province: West of Iran, 2011-2016. 2018;24:65-69. 


\section{Introduction}

Hepatitis $\mathrm{C}$ is a liver disease caused by hepatitis $\mathrm{C}$ virus $(\mathrm{HCV})$ (1). HCV is a blood-borne virus, usually transmitted through shared drug injection equipment, inadequate sterilization of medical equipment especially syringes and needles in health care settings, and blood transfusion (2). HCV can also be transmitted through sexual contact and can be transmitted from an infected mother to her child, however, this transmission mode is less common (3). The virus can cause either acute or chronic hepatitis, which ranges from a mild illness that lasts a few weeks to a serious and life-threatening illness (4). In total, approximately 71 million people are suffering from chronic hepatitis $\mathrm{C}$ infection; and a substantial proportion of people with the infection develop liver cirrhosis or liver cancer. Almost 399.000 people die each year from hepatitis $\mathrm{C}$, cirrhosis and cancer. Despite the favorable effectiveness of antiviral drugs to reduce the risk of liver carcinoma in nearly $95 \%$ of people infected with hepatitis $\mathrm{C}$, there is little universal access to diagnosis and treatment and no proved vaccine. Hepatitis $\mathrm{C}$ is found throughout the world; however, there are several species (or genotypes) of the HCV and their distribution varies by region (5). The highest annual incidence of $\mathrm{HCV}$ infection is observed in the Eastern and European Mediterranean offices of World Health Organization (WHO) (2.3\% and 1.5\%): while other offices have reported incidences from $0.5 \%$ to $1.0 \%$. Depending on the country, HCV infection can be concentrated in some populations (e.g. among people who inject drugs) and/or spreads across general population. Modeling studies have shown that there were 1.75 million new HCV infections (a total of 23.7 new HCV infections per 100.000 people) in 2015 (6). A trends analysis on the incidence rate of HCV from 2008 to 2013 showed that the overall incidence rate (per 100.000 people) varied from $0.55,0.72,1.44$, $2.69,1.24$ to 1.93 in Iran (7). The prevalence of HCV in one study in 2014 was estimated to be $0.2 \%$ (8). Another studies estimated the $\mathrm{HCV}$ prevalence ranging from $0.00 \%$ to $7.25 \%$ depending on the source populations in Iran $(9,10)$. Results of a systematic review also showed that the pooled prevalence of $\mathrm{HCV}$ was $0.3 \%$ in the general population, $6.2 \%$ in the populations at a moderate risk, $32.1 \%$ in the high-risk populations, and $4.6 \%$ in the specific clinical populations in Iran and according to finding of this study, the prevalence of hepatitis $C$ in Iran in the general population was less than $1 \%$ (11). Understanding the epidemiology of $\mathrm{HCV}$ is essential for developing cost-effective preventive strategies against $\mathrm{HCV}$. Therefore, the present study was conducted aiming atthe evaluation of epidemiology and trend of hepatitis C infection in Hamadan province during 2011-2016.

\section{Materials and Methods}

In this cross-sectional study, we used the information on the reported cases at the provincial level of the National Notifiable Diseases Surveillance System in Hamadan Province from 2011 to 2016.

Hamadan province is located in the west of Iran with an overall surface area of 19.546 square kilometers. According to the National Census, the population of the province was 1.758.268 in 2011. The province consists of 9 districts including Asadabad, Bahar, Hamadan, Famenin, Kabudarahang, Malayer, Nahavand, Tuyserkan and Razan.
According to the national guideline on viral hepatitis management, notification of hepatitis $B$ virüs and HCV infections is mandatory in Iran. Therefore, all public and private laboratories, blood transfusion organizations, hospitals and health centers should report all positive test results of serologic markers of HCV infection to the affiliated district health center on a monthly basis. A "suspected viral hepatitis" was defined based on the criteria of case definition by WHO $(6,12)$. To reach a homogenous and generalizable study sample, those patients who reside in other provinces were excluded. Moreover, cases with previous history of the disease were excluded and only incident cases in this period were enrolled. A complete examination checklist including information on demographic characteristics (age, gender, marital status, and residence), history of high-risk behaviors, and main reason for HCV examination was filled out by healthcare staff. The present study is based on recorded data from disease surveillance system, which was approved by the Deputy Chancellor of Health, and in fact, obtaining informed consent of the patients is not applicable.

Descriptive statistics, such as frequency tables and charts were used for presenting the results. The Cochran-Armitage test for linear trend was used to analyze the possible trends of disease incidence within the study period. Incidence risk of HCV infection (per 100.000 people) estimated by gender, location, marriage status and age group, and incidence risk ratio was computed for comparison of the incidence risks according to demographic characteristics.

\section{Statistical Analysis}

Data were analyzed using Stata (version 11.2, StataCorp, and College Station, Texas). A p value of 0.05 was considered statistically significant.

\section{Results}

Within this time period, a total of 803 new cases of HCV were registered, of whom705 (87.8\%) were male and 640 (79.9\%) were lived in urban areas. The mean age of the patients was $43.46 \pm 13.82$ years (range: $7-92$ year), and more than half of them (51\%) were in 25-44 years age group. As shown in Figure 1, the incidence of HCV infection ranged from 18.3 in 2011 to 9.38 in 2016 for males ( $p$ for trend=0.11) and ranged from 1.6 in 2011 to 1.14 in 2016 for females ( $p$ for trend=0.35).

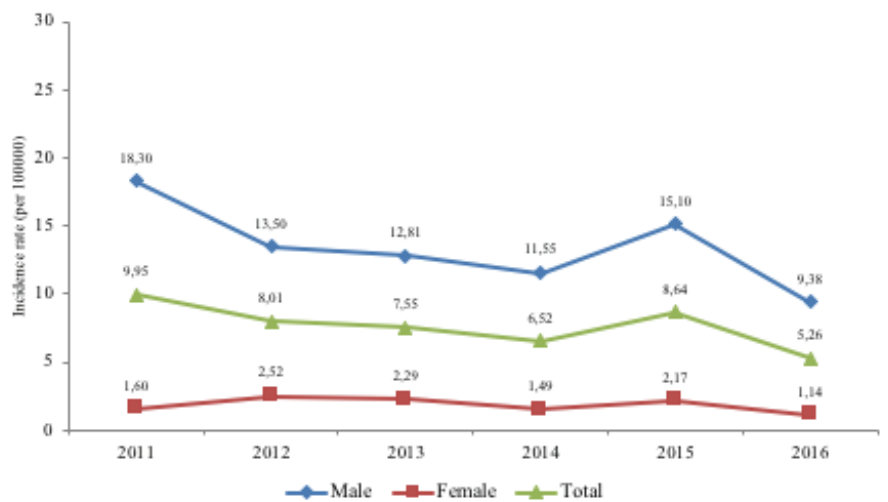

Figure 1. The incidence risk of hepatitis $C$ virus infection by gender and year 
Table 1. The incidence risk of hepatitis $C$ virus infection according to demographic variables

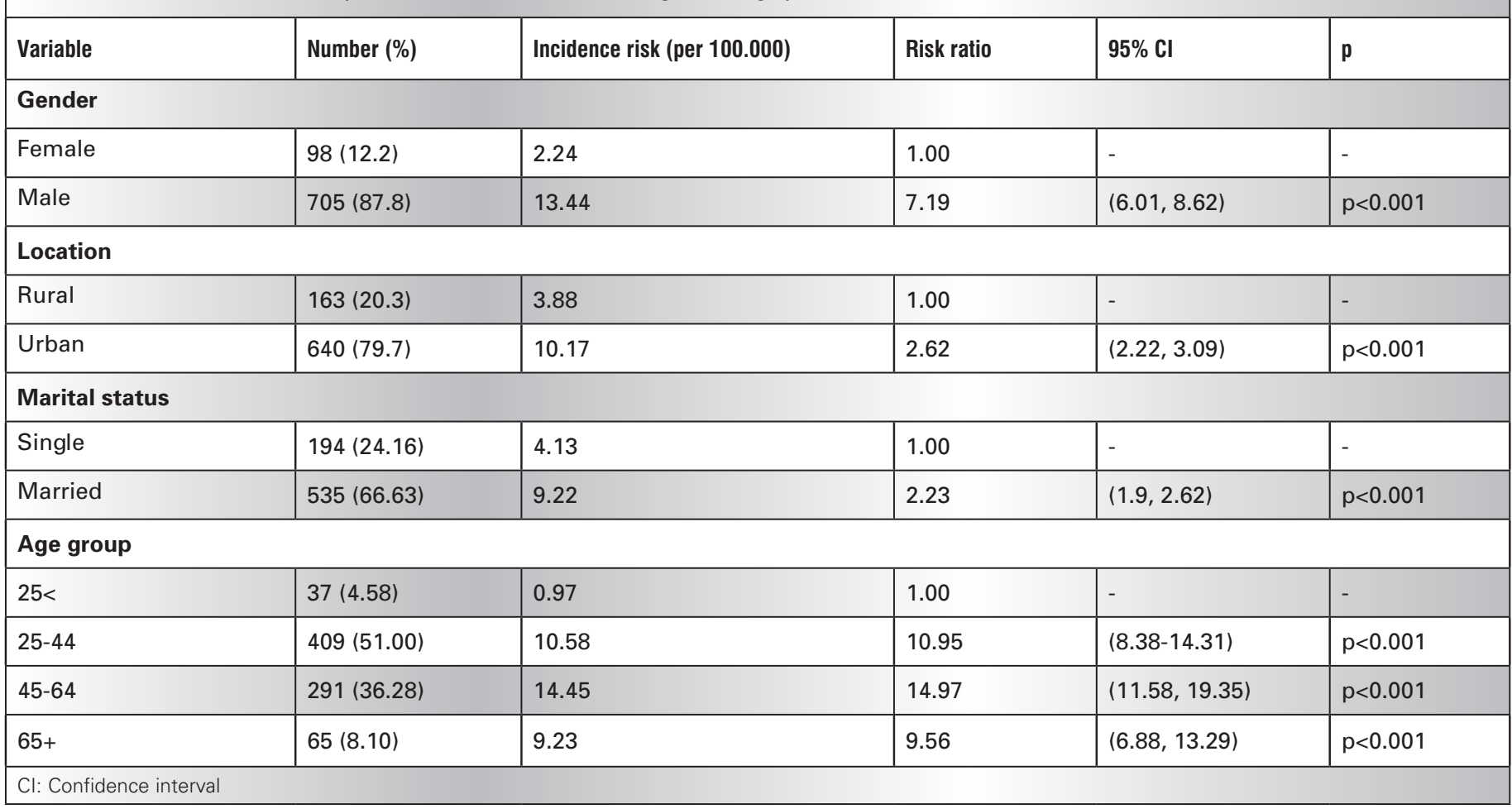

Table 1 shows the incidence risk of hepatitis $\mathrm{C}$ according to the demographic characteristics of the patients. The risk of hepatitis $\mathrm{C}$ in males was 7.19 times higher than in females $(p<0.001)$. Urban dwellers had 2.62 times higher risk of hepatitis $C(p<0.001)$. Being married was associated with more than two-fold increased risk; while compared to the age group of less than 25 years, those in the age group of 25-44, 45-64 and +65 had increased risk of HCV by $10.95,14.97$ and 9.56 time, respectively $(p<0.001)$.

The source of notification was clinical laboratory in 55.3\%; whereas $13.33 \%$ of them were reported by hospitals. The main reason for the examination was one's own free will due to the high-risk behaviors (Figure 2).

\section{Discussion}

In the present study, demographic and clinical information of 803 HCV-infected patients in Hamadan province were assessed for seven successive years from 2011 to 2016. Our findings indicated that HCV were reported more frequently in males, age group of 25-44 years, married people and urban dwellers. The overall incidence rate of HCV infection in Hamadan province was 5.26 per 100.000 in 2016, while southern counties had the higher incidence rate compared to the northern counties. The source of the notification was clinical laboratory for more than half of the patients. These findings are consistent with those reported in the literature $(7,12,13,14,15)$.

According to our findings, $\mathrm{HCV}$ infection is more common in self-employed, jobless and housekeepers. Our findings are similar to those carried out in other areas $(7,15)$. The findings of this study showed that more than $50 \%$ of cases of $\mathrm{HCV}$ were in the age group of 25-44 years. In addition, the risk of hepatitis $C$ in the age

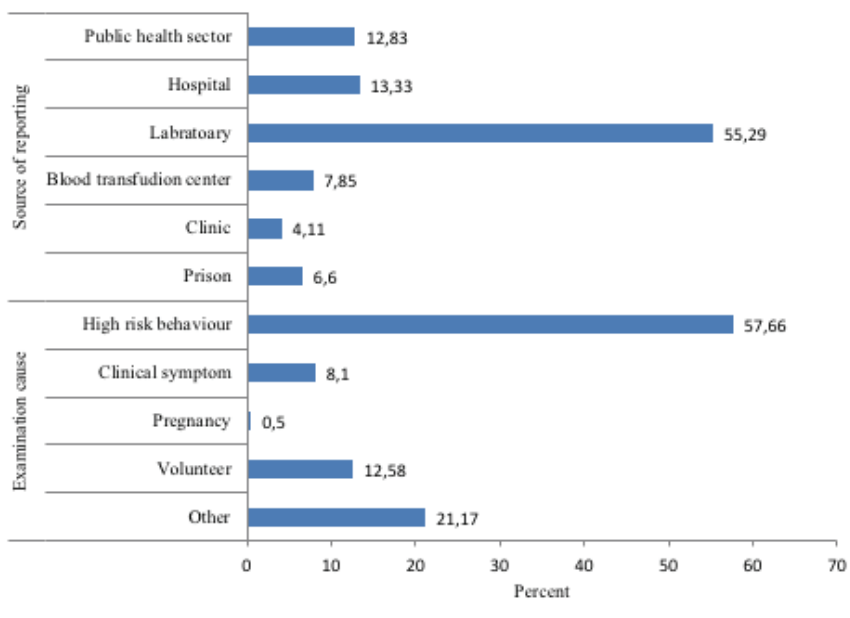

Figure 2. Source of notification and reason of examination of hepatitis C infected patients in Hamadan province (2011-2016)

group of 25-44 years was 10 times higher than in those younger than 25 years. The greater risk of HCV in this age group could be due to the higher social activity and thus more exposure to the risk factors.

In this study, the risk of hepatitis $\mathrm{C}$ in men was 7 times higher than that in women. Studies performed in Hormozgan, Khuzestan and Hamadan provinces confirmed this finding $(16,17,18)$, which reflect the extent of exposures to HCV risk factors for men. In the present study, the urban areas had the highest number of people with hepatitis which was similar to the results of studies done in Hamadan and Tehran $(17,18)$. Consistent with the results of a study from Kermanshah (19) we also found that most cases of hepatitis 
C were married, which could be attributed to the higher proportion of this subgroup and more social activity of these people.

Our findings are consistent with the previous epidemiological studies in other regions of the country $(7,20)$ and suggest a downward trend in the incidence of hepatitis $\mathrm{C}$ infection. The incidence of hepatitis $\mathrm{C}$ in Hamadan province decreased from 9.95 per 100.000 people in 2011 to 5.26 per 100.000 persons in 2016 in the general population. More specifically, the incidence of hepatitis C decreased from 18.3 in 2011 to 9.38 per 100.000 people in 2016 in men, and decreased from 1.6 to 1.14 in women. In general, due to the implementation of educational programs as well as effective therapeutic strategies on hepatitis $C$ disease by the Ministry of Health, the incidence of hepatitis $\mathrm{C}$ in Hamadan province is decreasing. There is currently no effective hepatitis C vaccine. Therefore, awareness programs for the transmission and prevention of hepatitis $\mathrm{C}$ in the community and for high-risk groups should be conducted by healthcare centers and mass media.

The present study suffered from a few limitations. Firstly, the collected data are based on the passive surveillance system, therefore, the findings are prone to underreporting. Secondly, HCV infection is usually without symptoms and patients are usually diagnosed accidentally during blood donation or screening during pregnancy, therefore, results strongly prone to underestimation.On the other hand, along with the mentioned limitations of passive surveillance systems, some advantages such as low cost and easier to carry out in comparison with active surveillance data encouraged us for using data from the passive system to monitor the trends of $\mathrm{HCV}$ and to provide critical information for monitoring a community's health.

\section{Conclusion}

Our results showed that HCV has a decreasing trend for both genders in Hamadan province and is mostly prevalent in males, age group of 25-44 years, married people and urban dwellers. Therefore, educational programs for the transmission and prevention of hepatitis $\mathrm{C}$ in the community and for high-risk groups should be conducted with the management of health centers and mass media. Further studies should explore the role of other risk factors in the HCV process and the reporting system.

Acknowledgments: We would like to thank the Deputy of Health of Hamadan University of Medical Sciences which collaborated in the data collection.

\section{Ethics}

Ethics Committee Approval: The present study is based on recorded data from disease surveillance system, which was approved by the Deputy Chancellor of Health.

Informed Consent: Hence this study used recorded data of disease surveillance system, informed consent of the patients is not applicable.

\section{Peer-review: Externally peer-reviewed.}

\section{Authorship Contributions}

Concept: A.M.Z., M.M., S.J.B., J.A., Design: S.K., S.N., J.A., Data Collection or Processing: M.S., M.M., S.J.B., Analysis or Interpretation: S.K., E.J., Literature Search: E.J., S.N., Writing: S.K., A.M.Z., S.N., E.J., M.M., S.J.B., M.S., J.A.
Conflict of Interest: The authors claim that they have no conflict of interest.

Financial Disclosure: The authors declared that this study received no financial support.

\section{References}

1. Adler M, Goubau P, Nevens F, Van HV. Hepatitis C virus: the burden of the disease. Acta gastro-enterologica Belgica. 2002;65:83-86.

2. Perez-Romero M, Sanchez-Quijano A, Lissen E. Transmission of hepatitis C virus. Ann Intern Med. 1990;113:411-412.

3. Pott $H$ Junior, Theodoro M, de Almeida Vespoli J, Senise JF Castelo A. Mother-to-child transmission of hepatitis $\mathrm{C}$ virus. Eur $\mathrm{J}$ Obstet Gynecol Reprod Biol. 2018;224:125-130.

4. Shepard CW, Finelli L, Alter MJ. Global epidemiology of hepatitis C virus infection. Lancet Infect Dis. 2005:5:558-567.

5. Stanaway JD, Flaxman AD, Naghavi M, Fitzmaurice C, Vos T, Abubakar I, Abu-Raddad LJ, Assadi R, Bhala N, Cowie B, Forouzanfour MH, Groeger J, Hanafiah KM, Jacobsen KH, James SL, MacLachlan J, Malekzadeh R, Martin NK, Mokdad AA, Mokdad $A H$, Murray CJL, Plass D, Rana S, Rein DB, Richardus JH, Sanabria J, Saylan M, Shahraz S, So S, Vlassov VV, Weiderpass E, Wiersma ST, Younis M, Yu C, El Sayed Zaki M, Cooke GS. The global burden of viral hepatitis from 1990 to 2013: findings from the Global Burden of Disease Study 2013. Lancet. 2016;388:1081-1088.

6. World heath Organization. Hepatitis C. 2017 [updated October 2017]; Available from: http://www.who.int/mediacentre/factsheets/ fs164/en/.

7. Khazaei S, Karami M, Ayubi E, Mohammadbeigi A, Hasanbeigi A, Mansori K, Mir-Shekar MR. Trends in epidemiology of Hepatitis $\mathrm{B}$ and $\mathrm{C}$ Infections in Ilam Province: National Notifiable Diseases Surveillance System data. Caspian J Intern Med. 2018;9:16-21.

8. Ebrahimzadeh A, Azarkar Z, Ziaee M, Sharifzadeh G, Bijari B. Prevalence and risk factors of hepatitis $C$ infection (HCV) in Birjand, Iran, 2014. International Journal of Infection. 2016;3.

9. Amiri FB, Mostafavi E, Mirzazadeh A. HIV, HBV and HCV coinfection prevalence in Iran-a systematic review and metaanalysis. PloS one. 2016;11:e0151946.

10. Rezaie M. Prevalence of hepatitis B, hepatitis C and HIV in blood donors in Semnan Province (Iran) from 2011 to 2015. Koomesh. 2016:501-508.

11. Mahmud S, Akbarzadeh V, Abu-Raddad LJ. The epidemiology of hepatitis $\mathrm{C}$ virus in Iran: Systematic review and meta-analyses. Sci Rep. 2018;8:150.

12. Afzali M, Mirzaei M. Epidemiology of hepatitis C in Islamic Republic of Iran. Asian Pac J Trop Dis. 2016;6:969-972.

13. Afzali M, Mirzaei M, Shoraka H, Saadati H. Epidemiological Survey of Hepatitis C in Yazd during 2010-2012: A Short Report. Journal of Rafsanjan University of Medical Sciences. 2015;13:1171-1178.

14. Aghamohamad A, Montazeri M, Akbari M. Prevalence of hepatitis B and hepatitis C in blood donors at Semnan province from 2008 to 2011. Koomesh. 2014:162-167.

15. Ghannad MS, Hojati SA, Mirzaei M, Sahebkar A. Prevalence of hepatitis $B$ and hepatitis $C$ in patients referred to health centers in the Hamadan province, Iran: an epidemiologic study of infections between 2004 and 2007. Asian Biomedicine. 2013;7:619-625.

16. Hajiani E, Hashemi J, Masjedizadeh R, Shayesteh AA, Idani E, Rajabi T. Seroepidemiology of hepatitis $C$ and its risk factors in Khuzestan Province, south-west of Iran: a case-control study. World Journal of Gastroenterology: WJG. 2006;12:4884. 
17. Merat $S$, Rezvan H, Nouraie M, Jafari E, Abolghasemi H, Radmard AR, Zaer-rezaii H, Amini-Kafiabad S, Maghsudlu M, Pourshams A, Malekzadeh R, Esmaili S. Seroprevalence of hepatitis C virus: the first population-based study from Iran. Int J Infect Dis. 2010;14 Suppl 3:e113-116.

18. Poorolajal J, Mirzaei M, Bathaei SJ, Majzoobi MM. Hepatitis B and C infections in hamadan province during 2004-2009. J Res Health Sci. 2011;11:51-57.
19. Babak S, Fatemehshamsedin S, Hossein K, Mansour R, Tannaz A, Siavash $V$, et al. Seroepidemiology of hepatitis $C$ in Kermanshah (West of Iran, 2006). Hepatitis Monthly. 2008;2008(2, Spring):141-146.

20. Khodabandehloo M, Roshani D, Sayehmiri K. Prevalence and trend of hepatitis $\mathrm{C}$ virus infection among blood donors in Iran: A systematic review and meta-analysis. J Res Med Sci. 2013;18:674-682. 